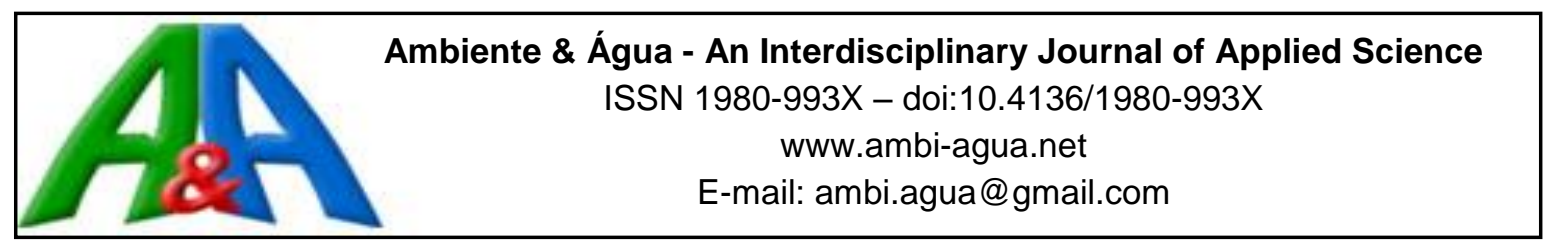

\title{
Heavy metals in waters used for human consumption and crop irrigation
}

\author{
ARTICLES doi:10.4136/ambi-agua.1999 \\ Received: 03 Sep. 2016; Accepted: 17 May 2018

\begin{abstract}
Laercio Santos Silva ${ }^{1}$; Izabel Cristina de Luna Galindo Clístenes Wilians Araújo do Nascimento²; Romário Pimenta Gomes; Ludmila de Freitas'; Ivanildo Amorim de Oliveira'; Milton César Costa Campos ${ }^{3 *}$; José Maurício da Cunha ${ }^{4}$

${ }^{1}$ Universidade Estadual Paulista "Júlio de Mesquita Filho" (UNESP), Jaboticabal, SP, Brasil Departamento de Solos e Adubos (FCAV/UNESP). E-mail: laerciosantos18@ gmail.com, rpgagronomia@gmail.com, ludmilafreitas84@gmail.com, ivanildoufam@gmail.com

${ }^{2}$ Universidade Federal Rural de Pernambuco (UFRPE), Recife, PE, Brasil

${ }^{3}$ Universidade Federal do Amazonas (UFAM), Humaitá, AM, Brasil

Colegiado de Agronomia. E-mail: mcesarsolos@gmail.com

${ }^{4}$ Universidade Federal do Amazonas (UFAM), Humaitá, AM, Brasil

Colegiado de Ciências: Física e Matemática. E-mail: maujmc@gmail.com

*Corresponding author
\end{abstract} \\ Departamento de Agronomia. E-mail: agromccc@yahoo.com.br, cwanascimento@yahoo.com
}

\begin{abstract}
The consumption of contaminated water is a major source of heavy metal contamination in humans and animals. This study therefore aimed to assess $\mathrm{Cd}, \mathrm{Cu}, \mathrm{Mn}, \mathrm{Ni}, \mathrm{Pb}$, and $\mathrm{Zn}$ levels in water used for human and animal consumption and vegetable crop irrigation in Camocim de São Félix, Pernambuco, Brazil. Water samples were collected on the studied farms from an artesian well and reservoirs used for human and animal consumption as well as for crop irrigation. The results showed that concentrations of $\mathrm{Cd}\left(>0.001 \mathrm{mg} \mathrm{L}^{-1}\right), \mathrm{Ni}\left(>0.025 \mathrm{mg} \mathrm{L}^{-1}\right)$ and $\mathrm{Pb}\left(>0.01 \mathrm{mg} \mathrm{L}^{-1}\right)$ were above the maximum allowable limits established under Brazilian law, indicating the need for a preventive monitoring program and immediate intervention initiatives aimed at the sources of contamination. The results demonstrate the need to quantify heavy metal content in vegetable crops, since their contamination by irrigation water may make them harmful to human health. Rainfall has a seasonal effect on heavy metal concentrations in water, showing a significant effect on $\mathrm{Pb}$ levels, whereas $\mathrm{Cd}$ and $\mathrm{Ni}$ content was less dependent on seasonal variation.
\end{abstract}

Keywords: agrochemicals, cadmium, diffuse pollution, lead, trace elements.

\section{Metais pesados em águas utilizadas para consumo humano e irrigação de culturas}

\section{RESUMO}

O consumo de águas contaminadas representa uma das principais vias de contaminação humana e animal por metais pesados. Neste sentido, o objetivo deste trabalho foi determinar as concentrações de $\mathrm{Cd}, \mathrm{Cu}, \mathrm{Mn}, \mathrm{Ni}, \mathrm{Pb}$ e $\mathrm{Zn}$ em águas utilizadas para consumo humano e animal 
e na irrigação de hortaliças no município de Camocim de São Félix (PE). Nas propriedades agrícolas, as amostras de água analisadas foram coletadas de poço artesiano e de reservatórios destinados ao consumo humano, animal e irrigação das lavouras. Os resultados demonstraram que as águas analisadas no presente estudo apresentaram concentrações de $\mathrm{Cd}$ (> 0,001 $\left.\mathrm{mg} \mathrm{L}^{-1}\right)$, Ni (>0,025 $\left.\mathrm{mg} \mathrm{L}^{-1}\right)$ e $\mathrm{Pb}\left(>0,01 \mathrm{mg} \mathrm{L}^{-1}\right)$ superiores aos teores máximos permitidos indicados pela legislação brasileira, sinalizando a necessidade de um programa de monitoramento preventivo e ações de intervenção imediata das fontes de contaminação. Os resultados indicam a necessidade de quantificação das concentrações de metais pesados nas hortaliças, visto que contaminadas pelas águas de irrigação podem ser uma fonte nociva à saúde humana. A precipitação pluviométrica tem influência sobre a variação sazonal dos teores dos metais nas águas, com maior efeito na concentração de $\mathrm{Pb}$ e influência moderada nas concentrações de $\mathrm{Cd}$ e Ni.

Palavras-chave: agroquímicos, cádmio, chumbo, elementos-traço, poluição difusa.

\section{INTRODUCTION}

Heavy metals can affect crop development and compromise the health of humans and animals by contaminating the food chain (Lee et al., 2006; Amin et al., 2013). In aquatic ecosystems, metals can occur naturally or be introduced by human activity. Natural occurrence is through atmospheric deposition and rainfall, or the release and transport of heavy metals from sediment or soil, in the case of soil erosion (Bezerra et al., 2014). Anthropogenic sources include raw sewage in urban areas and the discharge of industrial effluents and agricultural waste that widely contaminate basin areas (Gomes and Sato, 2011).

Agriculture is one of the most important sources of heavy metal pollution of bodies of water, largely through fertilizers $(\mathrm{Cd}, \mathrm{Cr}, \mathrm{Pb}, \mathrm{Zn})$ and pesticides $(\mathrm{Cu}, \mathrm{Pb}, \mathrm{Mn}, \mathrm{Zn})$ (Mendes et al., 2006, Silva et al., 2016). In this respect, although agrochemicals are a decisive factor in increasing yields, they can also cause heavy metal contamination (Mendes et al., 2010). For example, fertilizers made from phosphate rocks can increase levels of heavy metals such as $\mathrm{Cd}$, $\mathrm{Cu}, \mathrm{Mn}, \mathrm{Ni}, \mathrm{Pb}$ and $\mathrm{Zn}$ in the soil (Freitas et al., 2009).

In order to protect human health and ecosystems, monitoring agencies have established maximum allowable limits for heavy metals in water (CETESB, 2005; CONAMA, 2005). A study of water samples from the Caetés watershed in Paty de Alferes, Rio de Janeiro (RJ), found $\mathrm{Mn}, \mathrm{Cd}$ and $\mathrm{Pb}$ levels higher than the allowable limits stipulated by the National Environmental Council (CONAMA, 2005), attributed to atmospheric deposition and agricultural activities (fertilizers and agrochemicals) (Ramalho et al., 2000). Cunha Filho et al. (2014) analyzed crop irrigation water for the heavy metals $\mathrm{Fe}, \mathrm{Mn}, \mathrm{Zn}, \mathrm{Cu}, \mathrm{Pb}, \mathrm{Cd}$ and $\mathrm{Cr}$ and found that only $\mathrm{Fe}$ content $\left(0.908 \mathrm{mg} \mathrm{L}^{-1}\right)$ exceeded the allowable limit of $0.3 \mathrm{mg}$. $\mathrm{L}^{-1}$ (CONAMA, 2005).

In Pernambuco state, vegetable cultivation is concentrated in municipalities in the rural region, particularly Camocim de São Félix, where vegetable farming is the main economic activity. However, farmers in this area have used fertilizers without following technical criteria for at least 30 years, causing $\mathrm{N}$ and $\mathrm{P}$ contamination and eutrophication of water used for irrigation as well as human and animal consumption (Silva et al., 2001).

In this context, the present study measured levels of the heavy metals $\mathrm{Cd}, \mathrm{Cu}, \mathrm{Mn}, \mathrm{Ni}, \mathrm{Pb}$ and $\mathrm{Zn}$ in water used to irrigate vegetable crops and for human and animal consumption, in the municipality of Camocim de São Félix (PE), and compared them to the maximum allowable limits for these elements. Additionally, seasonal variations in water levels of these metals due to rainfall were also assessed. 


\section{MATERIAL AND METHODS}

The study was conducted in vegetable farming areas in the municipality of Camocim de São Félix, located in the southern rural region of Pernambuco state, in the Brejo Pernambucano microregion. Annual rainfall in the area is between 900 and $1300 \mathrm{~mm}$ and altitudes range from 600 to $1000 \mathrm{~m}$.

Water samples were taken from small dams in five vegetable farming areas along the slope. Samples were collected in loco and based on information obtained by the rural farmers and the Pernambuco Agronomic Institute (IPA). Each area had its own reservoir (R-1, R-2, R-3, R-4 and R-5), from which samples were taken of water used for crop irrigation as well as for human and animal consumption. Samples were also collected directly from a residential water source (artesian well). The reservoirs and residential well were georeferenced and the coordinates are shown in Table 1.

The areas containing the reservoirs are farmed using similar agricultural management systems, and exhibit an average $33 \%$ slope and consecutive annual vegetable crops. The farmers in this region use preventive and corrective irrigation and fertilizer/pesticide application during the different crops cycles. In this study, $200 \mathrm{~mL}$ of water was collected from the reservoirs each month, in addition to samples of the water used for human consumption, over a 12-month period (January to December 2010).

Table 1. Altitude, geographic coordinates and area of the bodies of water studied.

\begin{tabular}{|c|c|c|c|}
\hline Reservations: & Altitude (m) & Coordinates & Body of water $\left(\mathrm{m}^{2}\right)$ \\
\hline${ }^{\mathrm{a}} \mathrm{R}-1$ & 643 & S $8^{\circ} 22^{\prime} 34.5^{\prime \prime}$ and $\mathrm{W} 35^{\circ} 45^{\prime} 59.4^{\prime \prime} *$ & 7600 \\
\hline $\mathrm{R}-2$ & 640 & $\mathrm{~S} 8^{\circ} 22^{\prime} 37.0^{\prime \prime}$ and $\mathrm{W} 35^{\circ} 46^{\prime} 02.5^{\prime \prime}$ & 8100 \\
\hline $\mathrm{R}-3$ & 646 & $\mathrm{~S} 8^{\circ} 20^{\prime} 39.3^{\prime \prime}$ and W $35^{\circ} 45^{\prime} 04.9^{\prime \prime}$ & 5250 \\
\hline $\mathrm{R}-4$ & 656 & $\mathrm{~S} 8^{\circ} 20^{\prime} 36.7^{\prime \prime}$ and $\mathrm{W} 35^{\circ} 45^{\prime} 00.2^{\prime \prime}$ & 5950 \\
\hline $\mathrm{R}-5$ & 665 & $\mathrm{~S} 8^{\circ} 20^{\prime} 49.9^{\prime \prime}$ and $\mathrm{W} 35^{\circ} 44^{\prime} 58.1^{\prime \prime}$ & 6300 \\
\hline Home $^{b}$ & 699 & $\mathrm{~S} 8^{\circ} 21^{\prime} 50.2^{\prime \prime}$ and $\mathrm{W} 35^{\circ} 45^{\prime} 44.2^{\prime \prime}$ & --- \\
\hline
\end{tabular}

${ }^{\mathrm{a}} \mathrm{R}=$ reservoir; ${ }^{\mathrm{b}}=$ artesian well. $*$ data on altitude, coordinates and the bodies of water were obtained using a Garmin eTREX VISTA HCx GPS device.

Collections were performed between the $5^{\text {th }}$ and the $8^{\text {th }}$ of each month (January to December 2010) at different points of the reservoirs, avoiding areas with murky water or suspended material. At the residence, water was collected from a water outlet on the artesian well. An average of five subsamples were collected to form a $200 \mathrm{~mL}$ sample. The containers used for sampling were previously immersed in acidic solution $(3 \% \mathrm{HCl})$ for 24 hours.

The samples were immediately acidified with dilute nitric acid, at $1 \mathrm{~mL}$ of $\mathrm{HNO}_{3}$ for every $100 \mathrm{~mL}$ of sample. Once sealed, the flasks were kept in coolers and transported to the laboratory. On the same day they were collected, the samples were filtered in the laboratory using slow-filtering qualitative filter paper to prevent the release of low levels of the elements from the particulate material into the solution and stored in a refrigerator at $4{ }^{\circ} \mathrm{C}$. Concentrations of $\mathrm{Cd}, \mathrm{Cu}, \mathrm{Mn}, \mathrm{Ni}, \mathrm{Pb}$ were determined by flame atomic absorption spectrometry (Perkin Elmer AAnalyst 800), with detection limits for $\mathrm{Cd}$ (0.002), $\mathrm{Cu}$ (0.005), Mn (0.05), Ni (0.002), Pb (0.003) and $\mathrm{Zn}(0.002)$. For quality control purposes, samples of multielement standard solutions (spikes) were used, prepared based on $1000 \mathrm{mg} \mathrm{L}^{-1}$ standards (TITRISOL®, Merck), with concentration equal to the central point of the calibration curve of the device, for each chemical element.

The results were compared to the parameters established by Resolution 357 (CONAMA, 2005), which addresses the classification of bodies of water and their relevant environmental guidelines, as well as conditions and standards for effluent discharge. The resolution also

\section{IPABH}

Rev. Ambient. Água vol. 13 n. 4, e1999 - Taubaté 2018 
stipulates quality parameters for water for human and animal consumption, as well as irrigation of vegetables consumed raw and/or fruit that grows close to the ground and is eaten raw without removing the peel.

Monthly rainfall data for 2010 and the previous 10 years in the municipality of Camocim de São Félix were obtained from the Pernambuco Institute of Technology (Figure 1), to determine whether rainfall influenced heavy metal levels in the water analyzed (ITEP and LAMEPE, 2010).

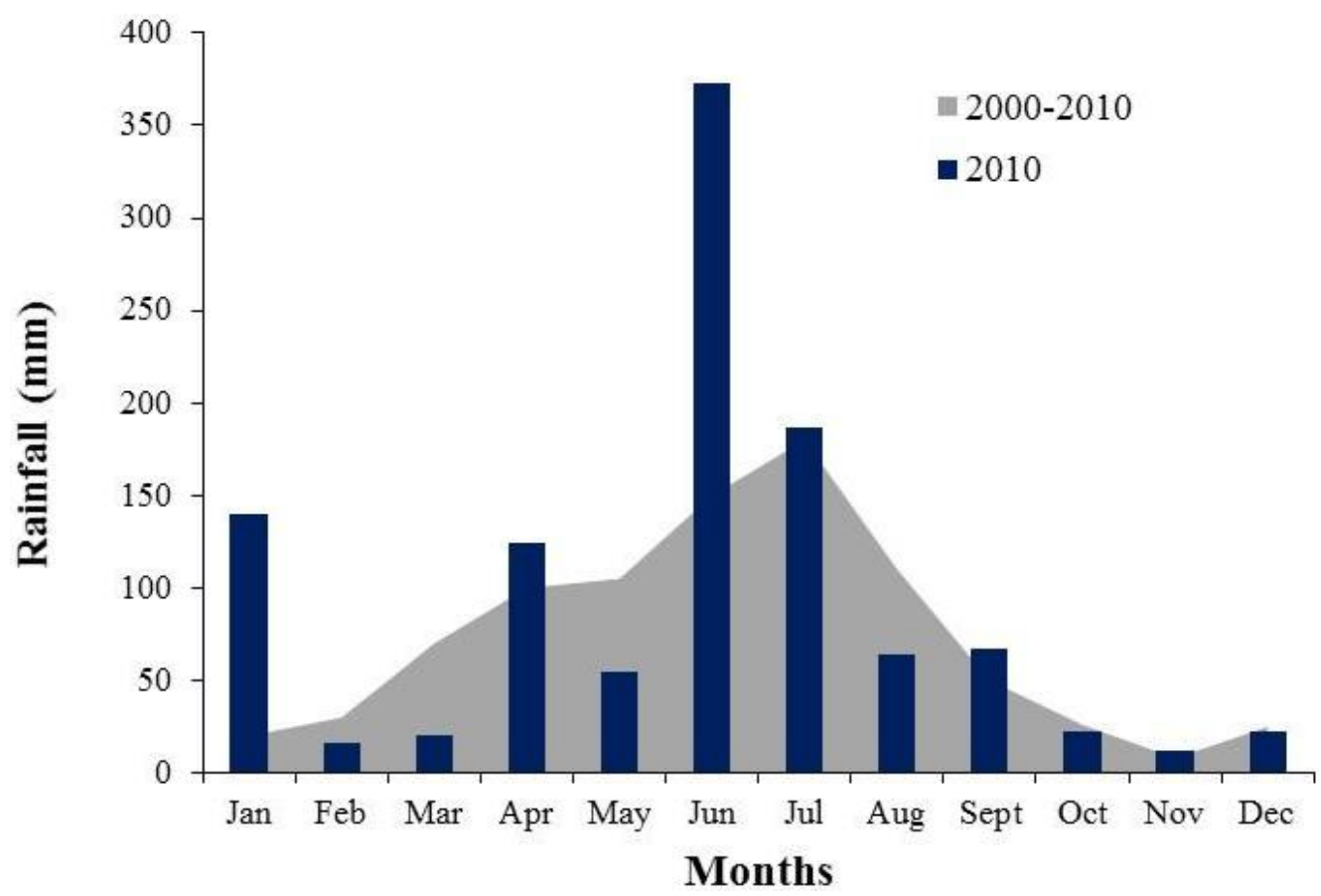

Figure 1. Mean monthly rainfall (January to December 2010) and historic mean in the municipality of Camocim de São Félix-PE. Source: Data provided by ITEP/LAMEPE, Camocim de São Félix Weather Station; * monthly rainfall in 2010 and 10-year average.

\section{RESULTS AND DISCUSSION}

$\mathrm{No} \mathrm{Cu}, \mathrm{Mn}$ or $\mathrm{Zn}$ was detected in water from the reservoirs and artesian well studied. These results are similar to those reported by Sobral et al. (2007), who recorded $\mathrm{Cu}, \mathrm{Mn}$ and $\mathrm{Zn}$ levels below the detection limit in water from the Cabedelo River (Rio Cabedelo), in the Mangabeira industrial district of João Pessoa (Paraíba state - PB).

Cd levels in the water samples varied from 0.041 to $0.058 \mathrm{mg} \mathrm{L}^{-1}$ (Table 2 and Figure 2), with all samples found to be above the established standard (CONAMA, 2005) of $0.001 \mathrm{mg} \mathrm{L}^{-1}$, indicating contamination of these water sources; a similar situation was reported by Paty do Alferes (RJ) (Ramalho et al., 2000) in Barra do Choça (Bahia state - BA). Cd is highly toxic and can cause poisoning when ingested in water or food (McGrath et al., 2006). The element is carcinogenic and can occur in agriculture through the use of pesticides and fertilizers (Sharma et al., 2007; Manzini et al., 2010).

Cd contamination in the water samples may be due to excessive use of phosphate fertilizers (Nacke et al., 2013; Gonçalves Júnior. et al., 2014; Benson et al., 2014; Balkhair and Ashraf, 2016). Around $60 \%$ of the $\mathrm{Cd}$ in triple superphosphate comes from phosphate rock. Bizarro et al. (2008) found $\mathrm{Cd}$ in the acidified $\mathrm{P}$ sources single and triple superphosphate, ranging from 2 to 13 and 3 to $33 \mathrm{mg} \mathrm{kg}^{-1}$, respectively. These values are relatively low; however, intensive 
farming using agrochemicals (fertilizers and pesticides) can increase heavy metal concentrations in the soil-water-plant system, especially in the case of elements poorly retained by the soil and easily lost to leaching (Singh and Agrawal, 2008; Freitas et al., 2009; Silva et al., 2016).

Table 2. Heavy metals in water samples from five reservoirs and an artesian well used to irrigate vegetable crops and for human and animal consumption in the municipality of Camocim de São Félix-PE.

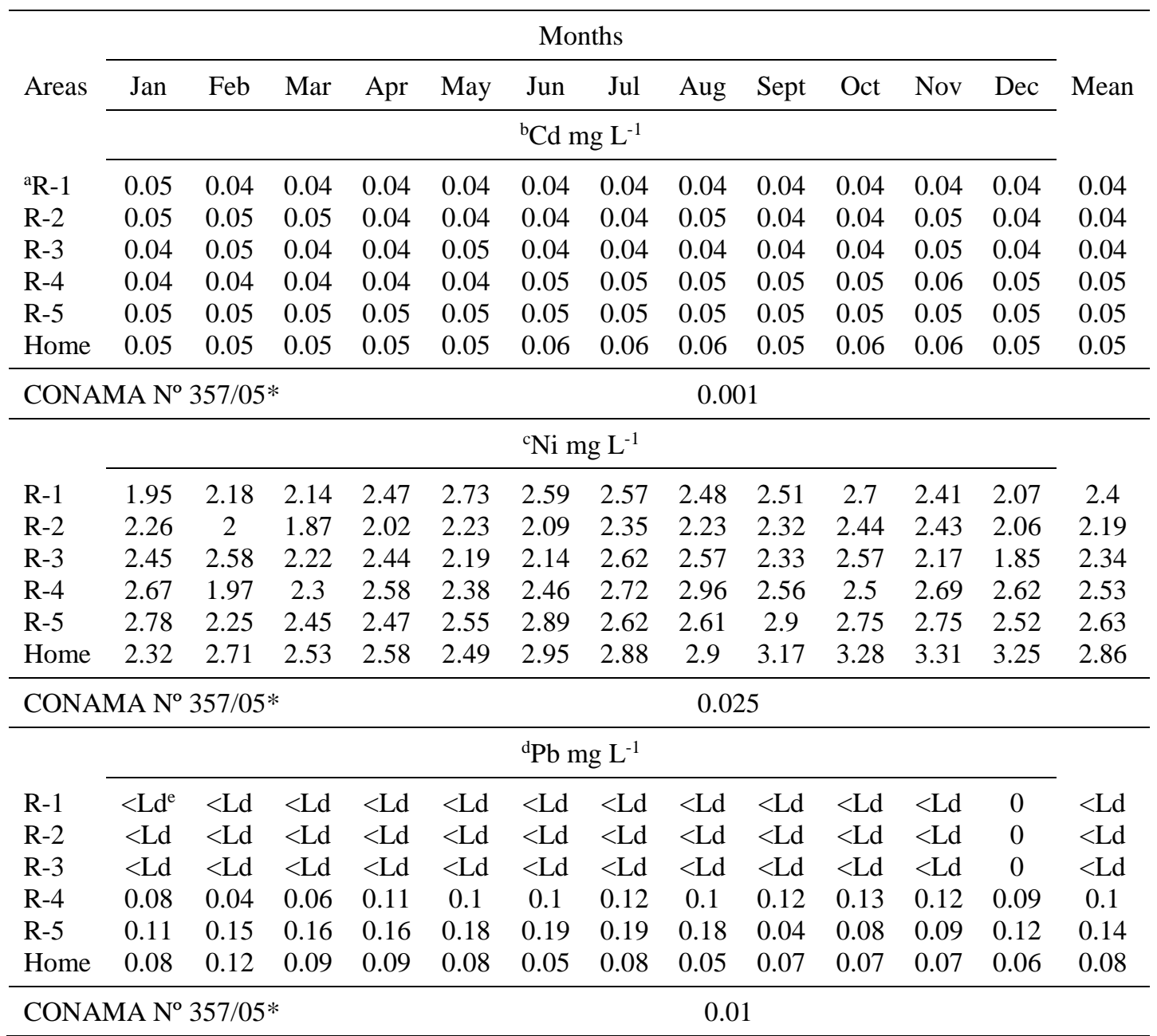

${ }^{\mathrm{a}} \mathrm{R}=$ reservoir; ${ }^{\mathrm{b}} \mathrm{Cd}=$ cadmium; ${ }^{\mathrm{c}} \mathrm{Ni}=$ nickel; ${ }^{\mathrm{d}} \mathrm{Pb}=\mathrm{lead} ;{ }^{\mathrm{e}} \mathrm{Ld}=$ not detected.

There were no changes in Cd content as a function of varying monthly rainfall, and only a slight increase in some of the reservoirs after periods of intense rainfall, possibly due to large amounts of sediment carried by erosion or more intense percolation of the element in the soil.

$\mathrm{Ni}$ levels in the water samples ranged from 1.85 to $3.31 \mathrm{mg} \mathrm{L}^{-1}$, at least 70 times higher than the established maximum allowable limit of $0.025 \mathrm{mg} \mathrm{L}^{-1}$ (Figure 3) (CONAMA, 2005), indicating significant nickel contamination of the bodies of water studied. This may also partially explain the decline in $\mathrm{Ni}$ in the cultivated areas, given its greater movement in the soil, which may favor leaching, leading to Ni contamination of the groundwater and, consequently, dammed water, exacerbated by evaporation. The rise in Ni levels after intense rainfall (January and June) may indicate the introduction of the metal along with sediment carried by erosion. 


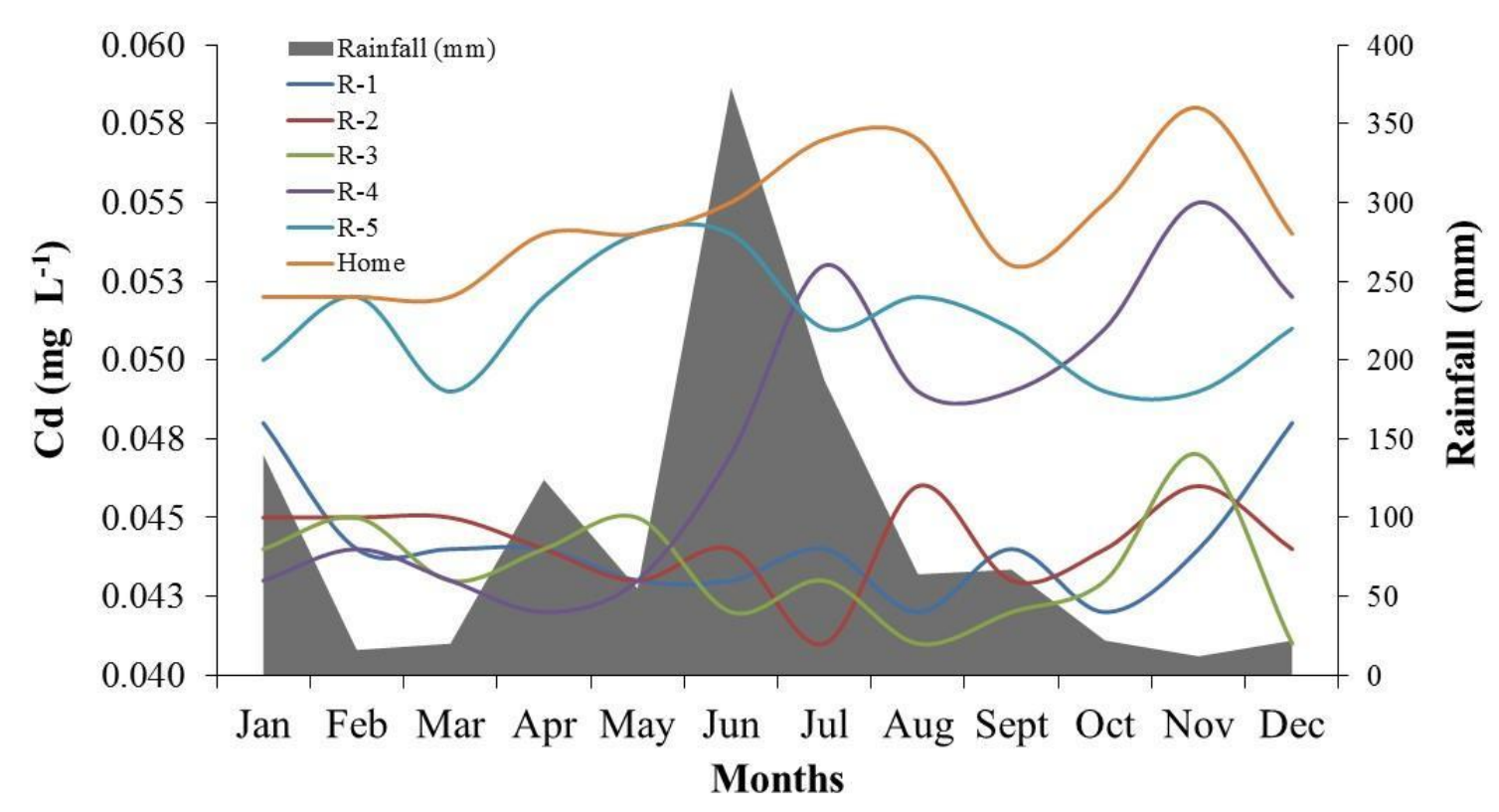

Figure 2. Influence of rainfall on the seasonal variation in cadmium $(\mathrm{Cd})$ concentration in water samples from five reservoirs (R) and an artesian well (home) used to irrigate vegetable crops and for human and animal consumption in the municipality of Camocim de São Félix-PE.

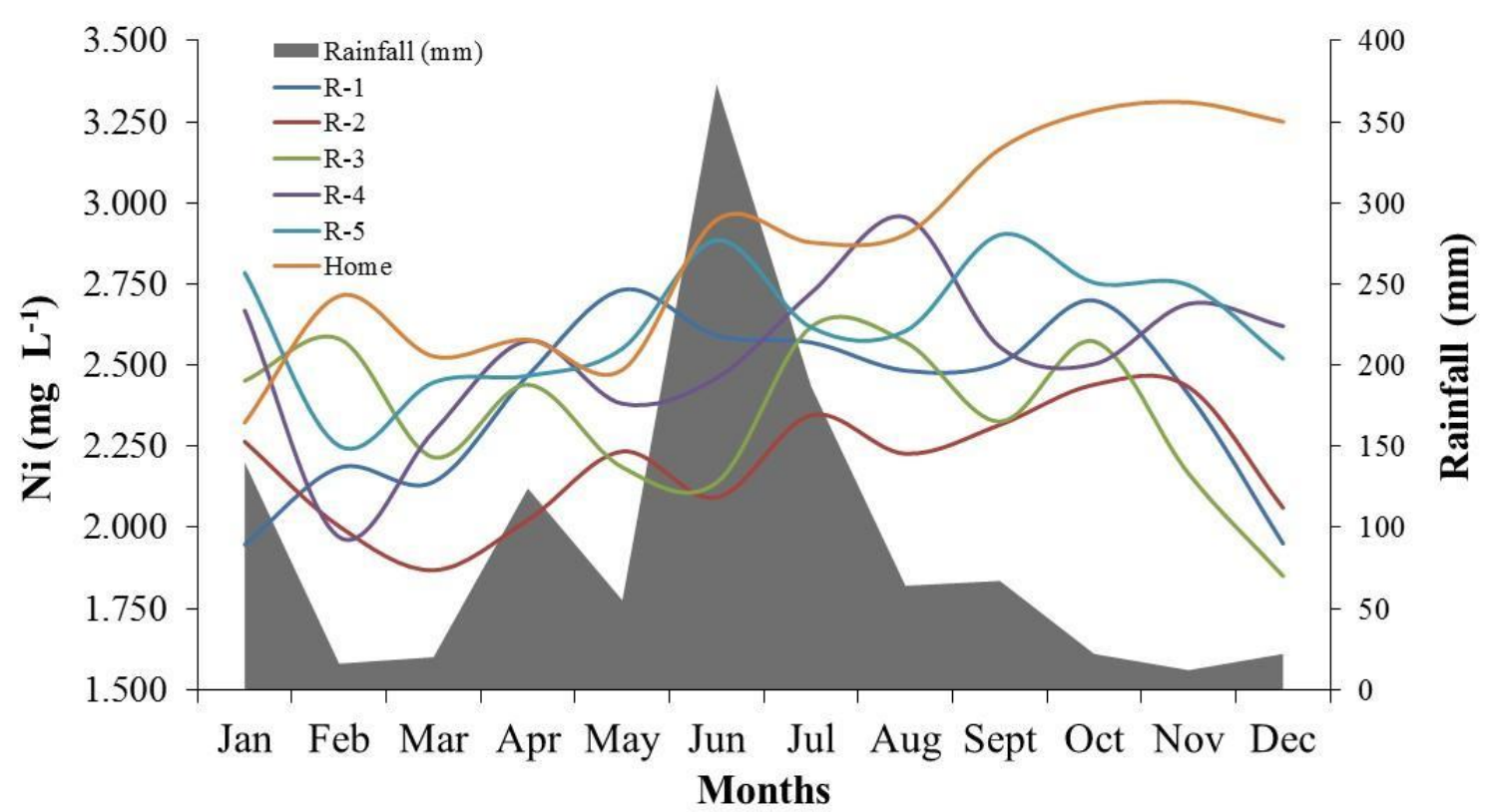

Figure 3. Influence of rainfall on the seasonal variation in nickel (Ni) concentration in water samples from five reservoirs (R) and an artesian well (home) used to irrigate vegetable crops and for human and animal consumption in the municipality of Camocim de São Félix-PE.

$\mathrm{Pb}$ content varied between 0.051 and $0.144 \mathrm{mg} \mathrm{L}^{-1}$ and was not detected in water from reservoirs R-1, R-2 or R-3 (Figure 4). Ramalho et al. (2000) studied heavy metal contamination in the Paty do Alferes watershed (RJ) and also found $\mathrm{Pb}$ levels higher than the maximum allowable limit. The values recorded in our study were higher than the established standard of $0.01 \mathrm{mg} \mathrm{L}^{-1}$, with R-5 exhibiting the highest $\mathrm{Pb}$ content. This reservoir supplies farming area AC5, which displayed the highest soil heavy metal levels, possibly due to the use of agrochemicals and the irrigation water itself (Vieira, 2011). 


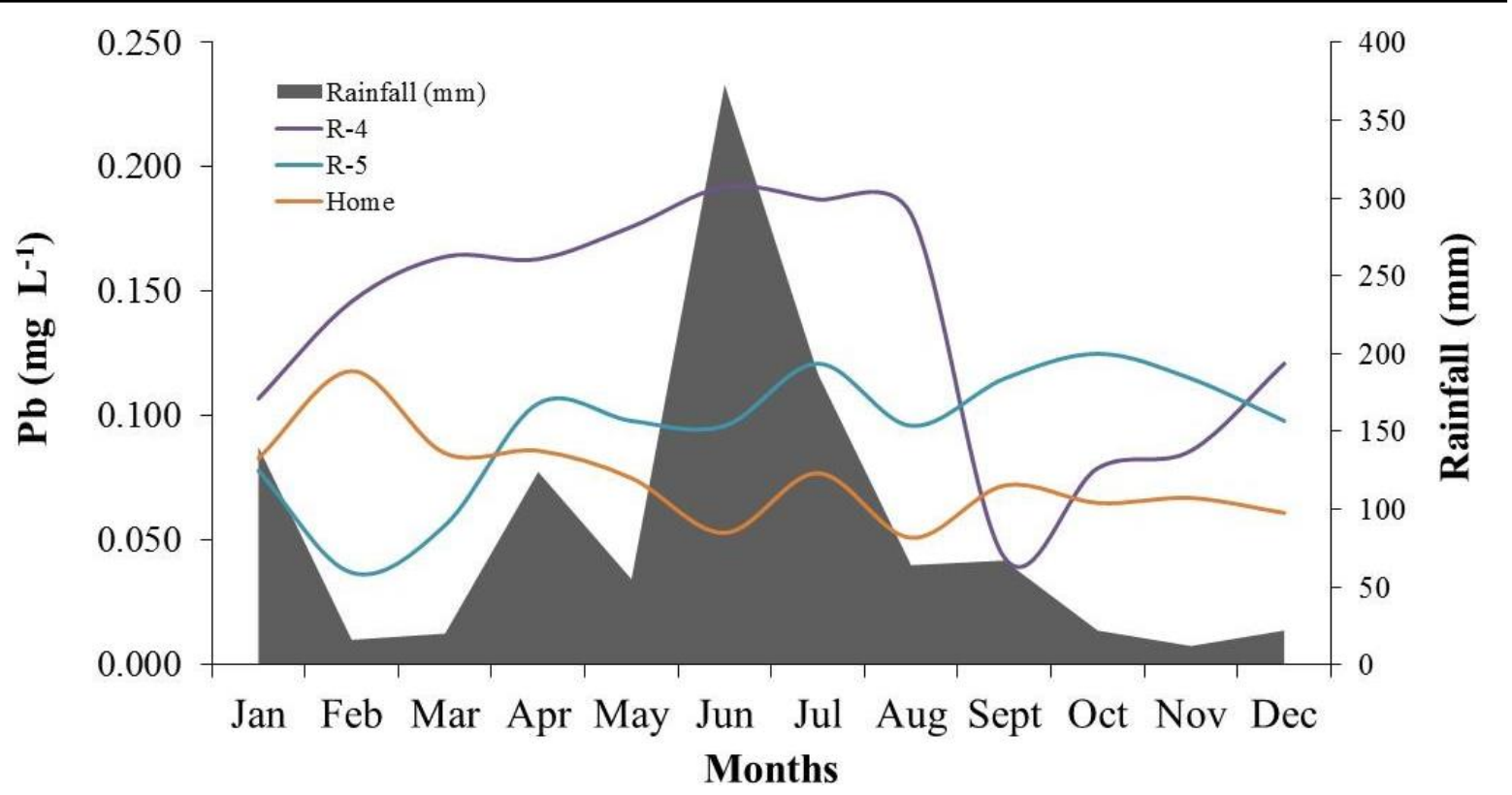

Figure 4. Influence of rainfall on the seasonal variation in lead $(\mathrm{Pb})$ concentration in water samples from five reservoirs (R) and an artesian well (home) used to irrigate vegetable crops and for human and animal consumption in the municipality of Camocim de São Félix-PE.

* $\mathrm{No} \mathrm{Pb}$ was detected in reservoirs $\mathrm{R}-1, \mathrm{R}-2$ and $\mathrm{R}-3$.

As such, given its low mobility in the soil, it is suggested that this metal is transported primarily by erosion and concentrates in the reservoir water; since this water is used for irrigation, the element returns to the soil and risks contaminating the vegetables grown on the site.

It is important to underscore that $\mathrm{Pb}$ content in the water consumed in the city, which is drawn from the subsoil (well) and distributed to homes without prior analysis or treatment, ranged from 0.051 to $0.086 \mathrm{mg} \mathrm{L}^{-1}$, that is, far higher than the limit stipulated by CONAMA (2005). Most $\mathrm{Pb}$ enters the human body through the respiratory and gastrointestinal tracts; once absorbed, it can be found in the blood and soft tissue and mineralized in bone (ATSDR, 2012). $\mathrm{Pb}$ can affect almost all the body's organs and systems, but the nervous system is the most sensitive, in both adults and children; the effect of the element is cumulative and causes chronic lead poisoning (CETESB, 2009).

The influence of rainfall on $\mathrm{Pb}$ levels declined in the months following the heaviest precipitation, suggesting a possible dilution effect, since $\mathrm{Pb}$ concentration rose again when rainfall was low and remained stable during those months.

In Brazil, there is almost no control over $\mathrm{Pb}$ pollution sources due to the lack of information on the actual exposure of the population (Neves et al., 2009). Thus, further research is needed in order to support public health authorities in initiatives to control environmental damage. The case of the municipality of Camocim de São Félix is an example of this scenario. The data in this study demonstrate the urgent need for additional studies on the issue, as well as environmental education measures and technical assistance, in order to reduce heavy metal contamination, thereby ensuring food security and water quality.

\section{CONCLUSIONS}

The water analyzed in the present study exhibited higher $\mathrm{Cd}, \mathrm{Ni}$ and $\mathrm{Pb}$ levels than the maximum allowable limits under Brazilian legislation, indicating the need for a preventive monitoring program and immediate intervention initiatives aimed at the sources of contamination. 
The results demonstrate the need to quantify heavy metal content in vegetable crops, since their contamination by irrigation water may make them harmful to human health.

Rainfall influences the seasonal variation in heavy metal levels in water, exhibiting a greater effect on $\mathrm{Pb}$ concentration and a moderate influence on $\mathrm{Cd}$ and $\mathrm{Ni}$.

\section{REFERENCES}

AMIN, N.; HUSSAIN, A.; ALAMZEB, S.; BEGUM, S. Accumulation of heavy metals in edible parts of vegetables irrigated with wastewater and their daily intake to adults and children, District Mardan, Pakistan. Food Chemistry, v. 36, n. 2, p. 1515-1523, 2013. https://doi.org/10.1016/j.foodchem.2012.09.058

AGENCY FOR TOXIC SUBSTANCES AND DISEASE REGISTRY - ATSDR. Public Health Service. Atlanta, 2012.

BALKHAIR, K. S.; ASHRAF, M. A. Field accumulation risks of heavy metals in soil and vegetable crop irrigated with sewage water in western region of Saudi Arabia. Saudi Journal of Biological Sciences, v. 23, n. 3, p. 32-44, 2016. https://doi.org/10.1016/j.sjbs.2015.09.023

BENSON, N. U.; ANAKE, W. U.; ETESIN, U. M. Trace Metals Levels in Inorganic Fertilizers Commercially Available in Nigeria. Journal of Scientific Research \& Reports, v. 3, n. 4, p. 610-620, 2014.

BEZERRA, J. D.; AMARAL, R. S.; SANTOS JÚNIOR, J. A. S.; GENEZINI, F. A.; MENEZES, R. S. C.; OLIVEIRA, I. A. Characterization of heavy metals in a uranium ore region of the state of Pernambuco. Springer, v. 92, n. 4, p. 270-273, 2014. https://doi.org/10.1007/s00128-013-1183-4

BIZARRO, V. G.; MEURER, E. J.; TATSCH, F. R. P. Teor de cádmio em fertilizantes fosfatados comercializados no Brasil. Ciência Rural, v. 38, n. 2, p. 247-250, 2008. http://hdl.handle.net/10183/22273

COMPANHIA DE TECNOLOGIA DE SANEAMENTO AMBIENTAL - CETESB. Relatório de estabelecimento de valores orientadores para solos e águas subterrâneas no Estado de São Paulo. São Paulo: SMA, 2005.

COMPANHIA DE TECNOLOGIA DE SANEAMENTO AMBIENTAL - CETESB. Significado ambiental e sanitário das variáveis de qualidade das águas e dos sedimentos e metodologias analíticas e de amostragem no Estado de São Paulo. São Paulo: SMA, 2009.

CONSELHO NACIONAL DE MEIO AMBIENTE (Brasil). Resolução nº 357, de 17 de março de 2005. Dispõe sobre a classificação dos corpos de água e diretrizes ambientais para o seu enquadramento, bem como estabelece as condições e padrões de lançamento de efluentes, e dá outras providências. Diário Oficial [da] União, 18 mar. 2005.

CUNHA FILHO, F. F.; NETTO, A. M.; NASCIMENTO, C. W. A.; BIONDI, C. M.; NETO J. A. S. Metais pesados em amostras de água de irrigação da maior região produtora de hortaliças folhosas de Pernambuco. Scientia Plena, v. 10, n. 7, p. 109-908, 2014.

FREITAS, E. V. S.; NASCIMENTO, C. W. A.; GOUlART, D. F.; SILVA, J. P. S. Disponibilidade de cádmio e chumbo para milho em solo adubado com fertilizantes fosfatados. Revista Brasileira de Ciência do Solo, v. 33, n. 3, p. 1899-1907, 2009. 
GOMES, M. V. T.; SATO, Y. Avaliação da contaminação por metais pesados em peixes do rio São Francisco à jusante da represa de Três Marias, Minas Gerais, Brasil. Saúde e Meio Ambiente Revista, v. 6, n. 2, p. 24-30, 2011.

GONÇALVES JÚNIOR., A. C.; NACKE, H.; SCHWANTES, D.; COELHO, G. F. Heavy metal contamination in brazilian agricultural soils due to application of fertilizers. In: HERNANDEZ-SORIANO, M. C. (Ed.). Environmental risk assessment of soil contamination. Rijeka: Intech Open, p. 105-135, 2014.

INSTITUTO DE TECNOLOGIA DE PERNAMBUCO - ITEP; LABORATÓRIO DE METEOROLOGIA DE PERNAMBUCO - LAMEPE. Estação Meteorológica de Camocim de São Félix (PE). São Félix 2010.

LEE, C. S.; LI, X.; SHI, W. Metal contamination in urban, suburban, and country park soils of Hong Kong: a study based on GIS and multivariate statistics. Science of the Total $\begin{array}{lllllll}\text { Environment, } & \text { v. } & 356, & \text { n. } & 4, & \text { p. } & 45-61,\end{array}$ https://doi.org/10.1016/j.scitotenv.2005.03.024

MANZINI, F. F.; SÁ, K. B.; PLICAS, L. M. A. Metais pesados: fonte e ação toxicológica. Fórum Ambiental da Alta Paulista, v. 6, n. 1, p.800-815, 2010.

MCGRATH, S. P.; LOMBI, W.; GRAY, C.W.; CAILLE, N.; DUNHAM, S. J.; ZHAO, F. J. Field evaluation of $\mathrm{Cd}$ and $\mathrm{Zn}$ phytoextraction potential by the hyperaccumulators Thlaspi caerulescens and Arabidopsis halleri. Environmental Pollution, v. 141, n. 2, p. 115-125, 2006. https://doi.org/10.1016/j.envpol.2005.08.022

MENDES, A. M. S.; DUDA, G. P.; NASCIMENTO, C. W. A.; SILVA, M. O. Bioavailability of cadmium and lead in a soil amended with phosphorus fertilizers. Scientia Agricola, v. 63, n. 2, p. 328-332, 2006. http://dx.doi.org/10.1590/S0103-90162006000400003

MENDES, A. M. S.; DUDA, G. P.; NASCIMENTO, C. W. A.; LIMA, J. A. G.; MEDEIROS, A. D. L. Acúmulo de metais pesados e alterações químicas em Cambissolo cultivado com meloeiro. Revista Brasileira Engenharia Agrícola e Ambiental, v. 14, n. 2, p. 791796, 2010.

NACKE, H.; GONÇALVES JÚNIOR, A. C.; SCHWANTES, D.; NAVA, I. A.; STREY, L.; COELHO, G. F. Availability of heavy metals $(\mathrm{Cd}, \mathrm{Pb}$ and $\mathrm{Cr})$ in agriculture from commercial fertilizers. Archives of Environmental Contamination and Toxicology, v. 64, n. 3, p. 537-544, 2013.

NEVES, E. B.; MENDONÇA, N. J.; RAMOS, M. Avaliação da exposição a metais pesados numa oficina de recuperação de armamento de uma organização militar. Ciência \& Saúde Coletiva, v. 14, n. 2, p. 2269-2280, 2009.

RAMAlho, J. F. G. P.; AMARAL SOBRINHO, N. M. B.; VElloso, A. C. X. Contaminação da microbacia de Caetés com metais pesados pelo uso de agroquímicos. Pesquisa Agropecuária Brasileira, v. 35, n. 7, p. 1289-1303, 2000. http://dx.doi.org/10.1590/S0100-204X2000000700002

SHARMA, R. K.; AGRAWAL, M.; MARSHALL, F. Heavy metal contamination of soil and vegetables in suburban areas of Varanasi, India. Ecotoxicology and Environmental Safety, v. 66, n. 2, p. 258-266, 2007. https://doi.org/10.1016/j.ecoenv.2005.11.007 
SILVA, A. B.; REZENDE, S. B.; SOUSA, A. R.; RESENDE, M.; FERRAZ, L. G. B. Principais características do sistema de produção de hortaliças no município de Camocim de São Félix, Pernambuco. Rio de Janeiro: Embrapa Solos, 2001. 29 p. (Embrapa Solos, Boletim de Pesquisa, Documentos 25).

SILVA, L. S.; GALINDO, I. C. L.; NASCIMENTO C. W. A.; GOMES, R. P.; CAMPOS M. C. C.; FREITAS, L.; OLIVEIRA, I. A. Heavy metal contents in Latosols cultivated with vegetable crops. Pesquisa Agropecuária Tropical, v. 46, p. 391-400, 2016. http:/dx.doi.org/10.1590/1983-40632016v4641587

SINGH, R. P.; AGRAWAL, M. Potential benefits and risks of land application of sewage sludge. Waste Management, v. 28, n. 3, p. 347-358, 2008. https://doi.org/10.1016/j.wasman.2006.12.010

SOBRAL, F. S.; DANTAS NETO, J.; LIMA, V. L. A.; LIRA, V. M.; FRANCO, E. S. Riscos sociais e ambientais devido a presença de metais pesados nas águas superficiais no distrito industrial de Mangabeira. QUALIT@S Revista Eletrônica, v. 6, n. 2, p. 81-91, 2007. http://dx.doi.org/10.18391/qualitas.v6i2.118

VIEIRA, L. P. Acumulação de nutrientes e metais pesados em solo, água e hortaliças em áreas cultivadas com olerícolas no agreste de Pernambuco. 2011. 109f. Dissertação (Mestrado) - Universidade Federal Rural de Pernambuco, Poço da Cruz, 2011. 